NBER WORKING PAPER SERIES

\title{
THE EFFECTS OF COMPUTERS ON CHILDREN'S SOCIAL DEVELOPMENT AND SCHOOL PARTICIPATION: EVIDENCE FROM A RANDOMIZED CONTROL EXPERIMENT
}

\author{
Robert W. Fairlie \\ Ariel Kalil \\ Working Paper 22907 \\ http://www.nber.org/papers/w22907 \\ NATIONAL BUREAU OF ECONOMIC RESEARCH \\ 1050 Massachusetts Avenue \\ Cambridge, MA 02138 \\ December 2016
}

We thank Computers for Classrooms, Inc., the ZeroDivide Foundation, and the NET Institute for generous funding for the project. We thank seminar participants at the IZA Conference on Risky Behaviors, CESifo Institute, and Teachers College at Columbia University, and Ben Hansen for helpful comments and suggestions. We thank the many school teachers, principals and administrators that helped run the computer giveaway program, which include Jennifer Bevers, Bruce Besnard, John Bohannon, Linda Coleman, Reg Govan, Rebecka Hagerty, Kathleen Hannah-Chambas, Brian Gault, David Jansen, Cynthia Kampf, Gina Lanphier, Linda Leonard, Kurt Madden, Lee McPeak, Stephen Morris, Joanne Parsley, Richard Pascual, Jeanette Sanchez, Zenae Scott, Tom Sharp, and many others. We thank Shilpa Aggarwal, Julian Caballero, David Castaneda, James Chiu, Samantha Grunberg, Keith Henwood, Cody Kennedy, Nicole Mendoza, Nick Parker, Miranda Schirmer, Glen Wolf and Heidi Wu for research assistance. Finally, special thanks go to Pat Furr for donating many computers for the study and distributing computers to schools. The views expressed herein are those of the authors and do not necessarily reflect the views of the National Bureau of Economic Research.

NBER working papers are circulated for discussion and comment purposes. They have not been peer-reviewed or been subject to the review by the NBER Board of Directors that accompanies official NBER publications.

(C) 2016 by Robert W. Fairlie and Ariel Kalil. All rights reserved. Short sections of text, not to exceed two paragraphs, may be quoted without explicit permission provided that full credit, including $\odot$ notice, is given to the source. 
The Effects of Computers on Children's Social Development and School Participation: Evidence from a Randomized Control Experiment

Robert W. Fairlie and Ariel Kalil

NBER Working Paper No. 22907

December 2016

JEL No. I20

\begin{abstract}
Concerns over the perceived negative impacts of computers on social development among children are prevalent but largely uninformed by plausibly causal evidence. We provide the first test of this hypothesis using a large-scale randomized control experiment in which more than one thousand children attending grades 6-10 across 15 different schools and 5 school districts in California were randomly given computers to use at home. Children in the treatment group are more likely to report having a social networking site, but also report spending more time communicating with their friends and interacting with their friends in person. There is no evidence that computer ownership displaces participation in after-school activities such as sports teams or clubs or reduces school participation and engagement.
\end{abstract}

Robert W. Fairlie

Department of Economics

Engineering 2 Building

University of California at Santa Cruz

Santa Cruz, CA 95064

and NBER

rfairlie@ucsc.edu

Ariel Kalil

Harris School of Public Policy

University of Chicago

1155 E. 60th Street

Chicago, IL 60637

a-kalil@uchicago.edu 


\section{Introduction}

Computer use among children has risen steadily over time and so too have concerns over its negative effects on social development. ${ }^{1}$ Concerns center on the substitution of actual interpersonal interactions with peers and parents for virtual ones, computer use's displacement of time on “developmentally meritorious” activities (e.g., sports and social activities), and the exposure to cyberbullying or other inappropriate digital media content (Subrahmanyam, Kraut, Greenfield \& Gross, 2001). For instance, increased computer use could displace putatively more meaningful face-to-face social contact and weaken social bonds with family and close friends (Kraut et al., 1998). ${ }^{2}$ In addition, time spent surfing the web, on social networking sites, or playing computer games is by definition time that cannot be allocated to sports, clubs, or other extracurricular activities. Participation in extracurricular activities is seen as a key forum for maintaining existing friendships and developing new ones (Crosnoe, 2011; Schaefer et al. 2011; Eccles \& Templeton, 2002). At its extreme, social isolation may increase children's avoidance of school through absences or chronic tardiness.

On the other hand, children's "alone time" on computers may extend social relationships by connecting with others through virtual interactions and actually facilitate subsequent interactions in person. In this way, computer ownership may complement, rather than substitute for, interpersonal interactions. Computers are used extensively for communication and social networking by children (Kaiser Family Foundation 2010; and Pew Internet Project 2013). The

\footnotetext{
${ }^{1}$ Currently 86 percent of children have access to a computer at home, though levels of access are much lower among minority and low-income children. See Bureau of Labor Statistics (2014); National Telecommunications and Information Administration (2013). Also, see Hoffman and Novak (1998); Servon (2002); Mossberger, Tolbert, and Stansbury (2003); Ono and Zavodny (2007); Fairlie (2004); Goldfarb and Prince (2008) for earlier examples of analyses of disparities in computer access.

${ }^{2}$ Similar concerns were expressed earlier over television crowding out more productive activities (see Zavodny 2006 for example).
} 
net effects of these opposing forces is unknown (Putnam 2000; Bauernschuster, Falck and Woessmann 2014).

Surprisingly, very few previous studies rigorously examine the effects of home computers on the social development of children. Two recent exceptions use quasi-experimental methods to explore the question. Malamud and Pop-Eleches (2010) use a regression discontinuity design (RDD) to estimate the effects of a government program in Romania that allocated a fixed number of vouchers for computers to low-income children in public schools. Their results showed little impact of home computers on children's engagement in sports or community service activities. Bauernschuster, Falck and Woessmann (2014) take advantage of a technological mistake in Internet service provision in Germany to estimate the effects of broadband access on social capital. Although the focus is on adults, they also examine effects on children's extra-curricular school activities such as sports, music, arts, and drama and do not find evidence of negative effects (Bauernschuster, Falck and Woessmann 2011).

To test the hypothesis that home computers affect social development among children, we conduct the first-ever randomized control experiment involving the provision of free computers to children for home use. Half of over one thousand children attending grades 6-10 attending 15 different schools (primarily middle) were randomly selected to receive computers to use at home. Several measures of social development were tracked over time for the treatment group of children receiving free computers and the control group of children not receiving free computers. The experimental design used here solves important problems of selection bias caused by families choosing to purchase computers for their children. In addition to being the first study to use a field experiment to explore the question, we also collected a broader range of measures of social development than prior studies, ranging from in person interactions with 
friends, to cyberbullying, to school participation. We also focus on adolescence because it is a sensitive period for the development and maintenance of peer interactions (Crosnoe, 2011) and thus a crucial time to understand the potentially adverse social developmental impacts of computer ownership. Earlier findings from the experiment indicate that home computers have no effect on educational outcomes, such as grades and test scores (Fairlie and Robinson 2013), but that study does not examine the effects on social development. ${ }^{3}$

We find that the field experiment has a large effect on computer ownership, total hours of computer use, and computer use for games, social networking and other entertainment among children. We find a significant and positive treatment impact on the number of friends children report communicating with and on the amount of time children report actually hanging out with their friends (in person). We find no evidence that children randomly assigned to receive a computer are less likely to participate on sports teams or after-school clubs, or spend less time in these activities. Finally, treated children are more likely to report using computers for communication and to have a social networking page. Thus, overall we find evidence of small positive benefits to children's social development and no statistically significant evidence of negative effects.

\section{Experimental Design}

To explore the effects of home computers on social development among children we conducted a randomized control experiment that provided free personal computers to over one thousand children for home use. It represents the first field experiment involving the provision of

\footnotetext{
${ }^{3}$ A larger literature explores the impact of home computers on educational outcomes, finding somewhat mixed results (for a few examples see Attewell \& Battle 1999; Fuchs \& Woessmann 2004; Fairlie 2005; Schmitt \& Wadsworth 2006; Fiorini, 2010; Malamud \& Pop-Eleches 2011; Mo et al. 2012; Fairlie and Robinson 2013; Vigdor et al. 2014; and see Bulman and Fairlie 2015 for a review).
} 
free computers to children for home use ever conducted. The randomized control experiment removes concerns about selection bias resulting from which families decide to purchase computers. None of the children participating in the study had computers at baseline. Half were randomly selected to receive free computers, while the other half served as the control group.

The sample for this study includes 1,123 children enrolled in grades 6-10 in 15 different middle and high schools in 5 school districts in California. The project took place over two years: 2008-9 and 2009-10. The 15 schools span the Central Valley of California geographically and capture both large and small schools, and urban and rural schools. The schools are primarily middle schools with 97 percent of the sample in grades 6-8. Overall, these schools are similar in size (749 students compared to 781 students), student to teacher ratio (20.4 to 22.6), and female to male student ratio (1.02 to 1.05) as California schools as a whole (U.S. Department of Education 2012). The schools attended by children participating in the experiment, however, are poorer (81\% free or reduced price lunch compared with 57\%) and have a higher percentage of minority students ( $82 \%$ to $73 \%$ ) than the California average reflecting the necessity of the experiment to require not having a home computer for eligibility. Participating children also have lower average test scores than the California average (3.2 compared with 3.6 in EnglishLanguage Arts and 3.1 compared with 3.3 in Math), but the differences are not large (California Department of Education 2010). Although these differences may impact our ability to generalize the results, low-income, ethnically diverse schools such as these are the ones most likely to enroll schoolchildren without home computers and be targeted by policies to address inequalities in access to technology (e.g. E-rate program and IDAs).

To identify children who did not already have home computers, we conducted an in-class survey at the beginning of the school year with all of the children attending one of the 15 
schools. The survey, which took only a few minutes to complete, asked basic questions about home computer ownership and usage. To encourage honest responses, it was not announced to children that the survey would be used to determine eligibility for a free home computer (even most teachers did not know the purpose of the survey). In total, 24 percent of children reported not having a computer at home. This rate of home computer ownership is roughly comparable to the national average: - estimates from the Current Population Survey indicate that $27 \%$ of children aged 10-17 do not have a computer with Internet access at home (U.S. Department of Education 2012).

Any child who reported not having a home computer on an in-class survey was eligible for the study. All eligible children were given an informational packet, baseline survey, and consent form to complete at home. To participate, children had to have their parents sign the consent form and return the completed survey to the school. Of the 1,636 children eligible for the study, we received 1,123 responses with valid consent forms and completed questionnaires (68.6\%). ${ }^{4}$ We randomized treatment at the individual level, stratified by school. In total, of the 1,123 participants, 559 were randomly assigned to the treatment group.

In discussing the logistics of the study with school officials, school principals expressed concern about the fairness of giving computers to a subset of eligible children. For this reason, we decided to give out computers to all eligible children: treatment children received computers immediately, while control children had to wait until the end of the school year. Our main

\footnotetext{
${ }^{4}$ This percentage is lowered by two schools in which $35 \%$ or fewer children returned a survey because of administrative problems at the school. However, there may certainly be cases in which children did not participate because they lost or did not bring home the flier advertising the study, their parents did not provide consent to be in the study, or they did not want a computer. Thus, participating children are probably likely to be more interested in receiving computers than non-participating children (which would also be the case in a real-world voucher or giveaway program). To deal with this, we focus on Intent-to-Treat effects in our main specifications. Note also that the results we present below are not sensitive to excluding the two schools with low participation rates.
} 
outcomes are all measured at the end of the school year, before the control children received their computers.

The computers provided through the experiment were purchased from or donated by Computers for Classrooms, Inc., a Microsoft-certified computer refurbisher located in Chico, California. The computers were refurbished Pentium machines with 17" monitors, modems, ethernet cards, CD drives, flash drives, Microsoft Windows, and Microsoft Office (Word, Excel, PowerPoint, Outlook). The computer came with a 1-year warranty on hardware and software during which Computers for Classrooms offered to replace any computer not functioning properly. In total, the retail value of the machines was approximately $\$ 400-500$ a unit. Since the focus of the project was to estimate the impacts of home computers on social participation among children and not to evaluate a more intensive technology policy intervention, no training or assistance was provided with the computers. We did not directly provide Internet service with the computers, but hardware was provided and the majority of children receiving free computers reported subscribing to service.

The computers were handed out by the schools to eligible children in the late fall of the school year. Almost all of the children sampled for computers received them: we received reports of only 11 children who did not pick up their computers, and 7 of these had dropped out of their school by that time. As expected, we found that some of the control group children purchased home computers by the end of the school year. From a follow-up survey conducted at the end of the school year, we found that 26 percent of children in the control group purchased computers, and in most cases these computers were purchased later in the school year (thus having less potential impacts on measured outcomes). After the distribution, neither the research team nor Computers for Classrooms had any contact with children during the school year. In 
addition, all of the outcome measures were collected at least 6 months after the computers were given out. Thus, it is very unlikely that child behavior would have changed for any reason other than the computers themselves (for instance, via Hawthorne effects).

\section{Data Sources}

Data from the experiment were collected from three main sources. First, we administered a detailed baseline survey which was required to participate in the project (as that was where consent was obtained). The survey includes detailed information on child and household characteristics. Second, each school provided us with detailed administrative data on school participation for all children covering the entire academic year. Finally, we administered a follow-up survey at the end of the school year, which included detailed questions about social development. We collected follow-up surveys for 85 percent of the children. The response rate was 84.3 percent for the control group and 85.4 percent for the treatment group (the difference is not statistically significant). ${ }^{5}$ Administrative data provided by the schools on school participation has essentially no attrition.

\section{Measures of Social Development}

To measure treatment effects on social development we conducted a follow-up survey at the end of the school year. Information on four broad categories of social development was included; i) computer-related behavior; ii) social interactions with friends; and iii) participation in after-school activities, and iv) school participation and engagement. Computer-related social behavior was assessed by asking whether the child ever showed their parent how to do

\footnotetext{
${ }^{5}$ We also do not find evidence that the characteristics of attritors differ between the treatment and control group. Specifically, we regress an attrition dummy variable on the controls interacted with treatment in addition to the main variables and do not find any differences.
} 
something on the computer, whether they have a social networking page, whether in the past school year they had ever been bullied, teased, or threatened online or by email, and whether in the past school year they had ever received help on school assignments from other students, friends, or teachers by email, instant messaging or networking.

We designed the questionnaire to include objective measures of social development to the extent possible. Appendix Table 1 reports the exact wording of each question. Because of the importance of the effects of home computers on peer interaction we measured this in several different ways. We asked teenagers about the number of friends they communicate with per week, the number they hang out with per week (in person), and the number of nights per week and number of hours per week they hang out with friends (in person). For after-school activities we asked whether the children participated on a sports team, the number of hours per week the child spends in sports or exercising, whether the child participates in any school clubs or other after-school activities, and the number of hours spent participating in clubs/after school activities.

Our fourth outcome measure is a multi-component objective assessment of school participation. All of the schools provided us with detailed administrative data on school participation at the end of the school year. The schools provided information on the number of absences, unexcused absences, days tardy and days suspended during the school year, and whether the child was still enrolled at the end of the school year.

\section{Summary Statistics and Randomization Verification}

Table 1 reports summary statistics for the treatment and control groups and provides a balance check. In the table, Columns 1 and 2 report the means for the treatment and control 
groups, respectively, while Column 3 reports the p-value for a t-test of equality. Demographic information from the school-provided administrative data and information from the baseline survey administered to all children is reported. The average age of study participants is 12.9 years. The sample has high concentrations of minority and non-primary English language students: 55\% of students are Latino, and 43\% primarily speak English at home. Most students, however, were born in the United States: the immigrant share is 19\%. The average education level of the highest educated parent is 12.8 years. From the baseline survey, we find that ninety percent of children live with their mothers, but only 58\% live with their fathers. Students report that $47 \%$ of mothers and $72 \%$ of fathers are employed (conditional on living with the student).

Overall, we find no differences between the treatment and control groups. None of the differences are statistically significant or large in magnitude. Nevertheless, we control for all of these covariates in the regressions that follow.

\section{Main Results}

\section{A. Computer Ownership, Usage and Activities}

The experiment has a very large first-stage impact in terms of increasing computer ownership and hours of computer use among children. Panel A of Table 2 reports treatment effects on computer ownership rates and total hours of computer use from the follow-up survey conducted at the end of the school year. The estimated treatment effects are from linear regressions that control for school, year, age, gender, ethnicity, grade, parental education, whether the student's primary language is English, whether the student is an immigrant, the number of people living in the household, whether the parents live with the student, and whether 
the parents have a job. ${ }^{6}$ Treatment effects estimates are also similar without controls. We find very large effects on computer ownership and usage. We find that $81 \%$ of the treatment group and $26 \%$ of the control group report having a computer at follow-up. While this first-stage treatment effect of 55 percentage points is very large, if anything it is understated because only a very small fraction of the 559 students in the treatment group did not receive one (as noted above, we had reports of only 11 children who did not pick up their computer). In addition, any measurement error in computer ownership would understate the first stage. The treatment group is also 25 percentage points more likely to report having Internet service at home than the control group (42\% of treatment children have Internet service, compared to $17 \%$ of control children).

We also have estimates of total time use on computers from the children. We do not want to overemphasize these specific estimates of hours use, however, because of potential measurement error common in self-reported time use estimates. With that caveat in mind, we find large first-stage results on reported computer usage (also reported in Panel A of Table 2). The treatment group reports using a computer 2.5 hours more per week than the control group, which represents a substantial gain over the control group average of 4.2 hours per week. The 4.2 hours that control students spend on computers is spent mostly at school and in other locations (i.e. libraries, or a friend or relative's house). But, we do not find evidence of more hours of computer use by the control group at other locations, including a friend's house, suggesting that these children did not indirectly benefit from using the computers at the homes of the treatment students. Reassuringly, this increase in total hours of computer use comes from home computer use. The similarity between the point estimate on total computer time and the point estimate on

\footnotetext{
${ }^{6}$ Some of these variables are missing for some children in the study. To avoid dropping these observations, we also include a dummy variable equal to 1 if the variable is missing and code the original variable as a 0 (so that the coefficients are identified from those with non-missing values). Estimates of treatment effects are similar dropping these observations.
} 
home computer time suggests that home use does not crowd out computer use at school or other locations.

The computers were used for both educational and non-educational purposes. In Panel B of Table 2 we estimate treatment effects on different activities by children. Children spend an additional 0.8 hours on schoolwork, 0.8 hours per week on games, 0.6 hours on social networking, and 0.4 hours on email. ${ }^{7}$ All of these increases are large relative to the control group means of $1.9,0.8,0.6$, and 0.3 , respectively. Though we do not want to overemphasize the specific point estimates given possible underreporting of time use, the finding of home computer use for both schoolwork and entertainment purposes among children is common to numerous national surveys of computer use (see Pew Internet Project 2008, 2012, 2013; U.S. Department of Education 2012; Kaiser Family Foundation 2010 for example). The findings are also suggestive that children report increased use of computers for activities that might be both social isolating (i.e. game use) and social participating (i.e. email and social networking).

\section{B. ITT vs. LATE}

We report the Intent-to-Treat (ITT) estimates of treatment effects from the experiment. LATE (or IV) estimates would be about twice as large (since the difference in computer usage is 55 percentage points). We do not report these estimates, however, because we cannot technically scale up the coefficients with the IV estimator because of differential timing of purchasing computers over the school year by the control group (two thirds of the control group with a home computer at follow-up obtained this computer after the fall). The finding that 82 percent of the treatment group reports having a computer at the end of the school year also creates difficulty in

\footnotetext{
${ }^{7}$ We also find larger medians and distributions that are to the right for the treatment group for these measures of schoolwork and game/networking use.
} 
scaling up the ITT estimates because we know that essentially all treatment children picked up their computers and that many of the treatment group reporting not having a computer at followup indeed had a computer at home (based on subsequent conversations with the children by principals). For these reasons we focus on the ITT estimates.

\section{Treatment Effects on Computer-Related Social Behavior}

Table 3 reports estimates of treatment effects on social behavior that is related to computer use. One clear benefit from having a computer at home is that children are more likely to report showing their parents how to do something on the computer. ${ }^{8}$ Having a home computer might increase communication between children and their parents as the children explain how to use computers. However, we do not find that home computers increase the likelihood that children receive help on school assignments from other students, friends, or teachers by email, instant messaging or social networking.

Having a home computer appears to increase the likelihood of having a social networking page. The estimated treatment (ITT) effect is sizeable and increases the percentage of the treatment group having a social networking page by nearly 10 percentage points or roughly 20 percent relative to the control group mean. This is consistent with the increased hours of use of computers for social networking reported in Table 2. The experiment increases the likelihood of reporting cyberbullying by 0.03 , which is not statistically significant but does nonetheless represent almost a 40 percent increase over the (relatively low) control group mean. ${ }^{9}$ We also do

\footnotetext{
${ }^{8}$ See Appendix Table 1 for the exact wording of this question and other social development questions on the follow-up survey.

${ }^{9}$ Cyberbullying has received a considerable amount of attention recently. See, for example, "How Big a Problem Is Bullying or Cyberbullying in Your School or Community?" NY Times, September 18, 2013, and "Experts Offer Their Guidance for Dealing With Online Bullying" NY Times, March 24, 2014.
} 
not find evidence indicating that children are more likely to receive help from a teacher or classmate through the Internet.

In interpreting these results, one should also keep in mind that many of the treated children did not establish an Internet connection. Because Internet connectivity was not provided as part of the experiment and thus not randomly assigned, it is not possible to accurately "scale up” the results for having a social networking page and experiencing cyberbullying by the share who actually established an Internet connection (i.e., LATE estimates for those with internet connections). Nevertheless, if one conducted this thought experiment ignoring likely selection into obtaining Internet service the impact of home computers with Internet connections on establishing a social network page and experiencing cyberbullying could be substantially larger.

All of these measures are directly related to social activities on computers. We now turn to examining measures of social development that are broader or independent of communicating through computers.

\section{Treatment Effects on Social Participation}

Home computers could lead to social isolation among children if real-time friendships and interactions are replaced by virtual ones or if computer use displaces activities that rely on or promote social engagement. Even with one activity such as gaming for example, children may become isolated playing games directly against the computer, but also get together to play the same games or interactive games (Orleans and Laney 2000).

We explore this question by examining the treatment effects on children's reports of social interactions with friends and participation in after-school clubs and activities. Table 4 reports estimates. We find that home computers actually increase the number of friends that 
children communicate with outside of school hours and increase the number of hours hanging out with friends (in person). Both of the estimated treatment effects are large relative to the control group mean. The treatment group communicates with an average of 1.57 more friends per work and hangs out for 0.72 more hours per week than the control group. For the other measures of social interactions with friends we find positive, but statistically insignificant point estimates.

To provide additional evidence on the overall effects of home computers on social participation we create a summary index that aggregates information over multiple treatment effect estimates (Kling, Liebman, \& Katz 2007). Specifically, we create an index of the social interaction with friends measures that combines the four measures reported in Table 4. By aggregating the separate educational outcomes we improve the statistical power of treatment effect estimates. To create the index we first calculate z-scores for each of the dependent variables by subtracting the control group mean and dividing by the control group standard deviation. Thus, each dependent variable has mean zero and standard deviation equal to one for the control group. The educational outcome index is then calculated from an equally-weighted average of the z-scores for the four dependent variables. The treatment effect estimate for this index indicates where the mean of the treatment group is in the distribution of the control group in terms of standard deviation units.

Appendix Table 2 reports estimates for the social interaction with friends outcome index. By definition the control group mean for the index is 0 . The treatment effect estimate is positive and statistically significant. The point estimate of 0.10 implies that the treatment group mean is 0.10 standard deviations higher than the control group mean. The treatment effect estimate for 
the summary measure of educational outcomes provides additional evidence that home computers increase social interactions with friends.

In Table 5, we examine the effects of home computers on another measure of social development by examining participation in sports, clubs, and other after-school activities. Participation in after-school activities provides an important and objective measure of social development. Being part of a sports team, club, or music group is hypothesized to promote children's intellectual and emotional adjustment in part because doing so provides an organized forum for positive peer engagement, thereby generating social and human capital (Eccles \& Barber, 1999; Eccles \& Templeton, 2002; Feldman \& Matjasko, 2005; Mahoney et al. 2009). Using measures of after-school sports and club participation and hours, we find no evidence of negative effects of home computers. Estimates for a summary z-score for these four variables confirm this finding (see Appendix Table 2). Having a home computer does not appear to lead to increasing social isolation by crowding out after-school activities.

\section{E. Treatment Effects on School Participation and Engagement}

We also measure whether home computers affect participation and engagement in school through their impacts on the number of absences, unexcused absences, tardies and days suspended, and whether the child was still enrolled in the school at the end of the school year. Any negative social impacts of home computers might spill over into how schoolchildren participate and engage in school. We measure each of the outcomes as both the number of events (i.e. times or days) and incidence (i.e. 0/1). Table 6 reports estimates for each measure, and Appendix Table 2 reports the summary z-score estimate. We find no evidence of negative effects of home computers on school participation and engagement. 


\section{Treatment Heterogeneity}

In this section, we explore heterogeneity in treatment effects by various baseline characteristics. We focus specifically on pre-treatment measures of social participation, social communication, and parental controls. Table 7 reports estimates of heterogeneous treatment effects for prior social participation and parental controls. We first report estimates for interacting treatment with children reporting hanging out with many friends at baseline (defined as 4 or more which is roughly the median). We do not find evidence of differential treatment effects by baseline interaction with hanging out with many friends. We also report estimates for interacting treatment with children reporting that they have a curfew at baseline. We find a couple of positive treatment interaction point estimates with one being statistically significant, but the results are not strong. It might be that the computer enabled children who have a curfew to reach out to more friends because they can now communicate with those friends more easily when they are at home.

In Table 8, we focus on measures of prior social communication. On the baseline survey we asked children if they had a social networking page (which 40 percent did) and whether they sent text messages (which 35 percent did). We interact treatment with both of these measures of pre-treatment social communication. We find some evidence suggesting a positive relative effect on social participation outcomes for students who did not use these forms of communicating with friends at baseline. The home computers allowed these children who were previously socially participating at lower levels to catch up, or at least partially catch up, with children who were previously socially participating at higher levels (note the interaction treatment effects are large relative to the negative main effects). Thus, rather than increasing social isolation as has been 
feared by some, access to home computers appears to play a compensatory role for those students who were initially relatively less socially connected in the digital world.

We also examined treatment heterogeneity by gender, ethnicity and grade level. Appendix Table 3 reports estimates. We do not find statistically significant treatment interactions across these demographic groups.

\section{Conclusion}

Do computers inhibit children's social development and lead to social isolation, or do they facilitate in-person interactions with friends and schoolmates? There is surprisingly little credible research addressing this question. We provide the first relevant evidence using a randomized control experiment. The field experiment involved the random provision of computers to use at home to more than one thousand children attending 15 different schools. We found that home computers increase total use of computers for social networking and email among children as well as the total use of computers for games and other entertainment. Far from being socially isolating, however, we find a significant and positive impact on the number of friends treated children report communicating with and on the amount of time children report actually hanging out with their friends in person. We also find no evidence that children randomly assigned to receive a computer are less likely to participate in sports teams or afterschool clubs, or spend any less time in these activities. All told, the results portray a pattern of small positive benefits to youth’s social development and no significant evidence of increasing social isolation, at least according to the outcomes we have measured here.

The underlying mechanisms that give rise to these effects merit further exploration. Children might spend time alone at home on the computer, but computers may provide 
opportunities for communication with others and a focus point for friends to gather around. Increased computer time also does not appear to displace other social activities, but this requires further study. Clearly, a treatment-induced increase in time spent on the computer and hanging out with friends must be offset by a reduction in time spent on something else. Our follow-up survey provides information on TV time, homework time, and reading (non-homework) time, but we did not find negative (or positive) treatment-control differences for any of these variables. Indeed, the treatment point estimates were all very close to zero with or without controls. The time could be coming from activities that we did not measure such as sleeping, time with family, eating, and exercising, but we cannot be sure. Further research in this vein could consider including a time diary that forces a summing up of time across activities and results in more accurate measures of time use along with including more options. However, such time diaries are difficult to administer, time consuming, and often experience low response rates among children.

Additional measures of social development may also be important and merit further study. Moreover, home computers may increase social and academic development by increasing home-school connections. One clear benefit from having a computer at home is that children are more likely to report showing their parents how to do something on the computer. We also find some evidence from our experiment of a positive effect of home computers on whether parents check assignments, grades and attendance online using student information system software. (results not reported here). These types of software, which provide parents with nearly instantaneous information on their children's school performance, attendance and disciplinary actions, are becoming increasingly popular in schools. More research is needed on how access to home computers affects home-school connections such as these and how they ultimately affect children's social and academic development. 


\section{References}

Attewell, P. \& Battle, J. (1999). Home Computers and School Performance. The Information Society 15: 1-10.

Bauernschuster, Stefan, Oliver Falck, and Ludger Woessmann. (2014) Surfing alone? The Internet and social capital: Evidence from an unforeseeable technological mistake. Journal of Public Economics 117: 73-89.

Bauernschuster, Stefan, Oliver Falck, and Ludger Woessmann. (2011). Surfing Alone? The Internet and Social Capital: Evidence from an Unforeseeable Technological Mistake. CESifo Working Paper 3469. CESifo, Munich.

Bulman, George, and Robert W. Fairlie. (2015). "Technology and Education: Computers, Software, and the Internet," Handbook of the Economics of Education, Vol. 5, eds Eric Hanushek, Steve Machin, and Ludger Woessmann, North-Holland, Chapter 6: 239-280.

California Department of Education (2010). 2010 STAR Test Results: California STAR Program, http://star.cde.ca.gov/star2010/

Crosnoe, R. (2011). Fitting In, Standing Out: Navigating the Social Challenges of High School to Get an Education. New York: Cambridge University Press.

Eccles, J. S., \& Barber, B. L. (1999). Student council, volunteering, basketball, or marching band: What kind of extracurricular involvement matters? Journal of Adolescent Research, 14, 10-43.

Eccles, J. S., \& Templeton, J. (2002). Extracurricular and other after-school activities for youth. Review of Research in Education, 26, 113-180.

Fairlie, Robert W. (2004). "Race and the Digital Divide," Contributions to Economic Analysis \& Policy, The Berkeley Electronic Journals 3(1), Article 15: 1-38.

Fairlie, R. (2005). The Effects of Home Computers on School Enrollment. Economics of Education Review 24, 533-547.

Fairlie, R., \& Robinson, R. (2013). Experimental Evidence on the Effects of Home Computers on Academic Achievement among Schoolchildren. American Economic Journal: Applied Economics, 5, 211-40.

Feldman, A. \& Matjasko, J. (2005). The role of school-based extracurricular activities in adolescent development: A comprehensive review and future directions. Review of Educational Research, 75, 159-210.

Fiorini, M. (2010). The Effect of Home Computer Use on Children's Cognitive and NonCognitive Skills. Economics of Education Review 29, 55-72. 
Fuchs, T., \& Woessmann, L. (2004). Computers and Student Learning: Bivariate and Multivariate Evidence on the Availability and Use of Computers at Home and at School. CESifo Working Paper No. 1321.

Goldfarb, A. \& Prince, J. (2008). Internet Adoption and Usage Patterns are Different: Implications for the Digital Divide. Information Economics and Policy 20, 2-15.

Kaiser Family Foundation. (2010). Generation $M^{2}$ : Media in the Lives of 8- to 18-Year Olds. Kaiser Family Foundation Study.

Kling, J., Liebman, J., \& Katz, L. (2007). Experimental Analysis of Neighborhood Effects. Econometrica 75, 83-119.

Kraut, R., Patterson, M., Lundmark, V., Kiesler, S., Mukopadhyay, T., \& Scherlis, W. (1998). Internet paradox: A social technology that reduces social involvement and psychological well-being? American Psychologist, 53, 1017-1031.

Mahoney, J. L., Vandell, D. L., Simpkins, S., \& Zarrett, N. (2009). Adolescent out-of-school activities. In R. M. Lerner \& L. Steinberg (Eds.), Handbook of adolescent psychology: Vol. 2. Contextual influ-ences on adolescent development (3rd ed., pp. 228 -269). Hoboken, NJ: Wiley.

Malamud, O. \& Pop-Eleches, C. (2011). Home Computer Use and the Development of Human Capital. Quarterly Journal of Economics 126, 987-1027.

Mo, D., Swinnen, J., Zhang, L., Yi, H., Qu, Q., Boswell, M., and Rozelle, S. 2012. "Can One Laptop per Child Reduce the Digital Divide and Educational Gap? Evidence from a Randomized Experiment in Migrant Schools in Beijing," Rural Education Action Project, Stanford University, Working Paper 233.

Mossberger, K., Tolbert, C., \& Stansbury, M. (2003). Virtual Inequality: Beyond the Digital Divide. Georgetown University Press, Washington, DC.

National Telecommunications and Information Administration. (2013). Exploring the Digital Nation: America’s Emerging Online Experience.

Ono, H. \& Zavodny, M. (2007). Digital Inequality: A Five Country Comparison Using Microdata. Social Science Research 36, 1135-1155.

Orleans, M., and M. Laney. 2000. "Children’s Computer Use in the Home: Isolation or Socialization?," Social Science Computer Review. 18(1): 56-72. 
Pew Internet Project. 2008. Teens, Video Games, and Civics: Teens' gaming experiences are diverse and include significant social interaction and civic engagement, Washington, D.C.: Pew Internet \& American Life Project.

Pew Internet Project. 2012. How Teens Do Research in the Digital World, Washington, D.C.: Pew Internet \& American Life Project, http://www. pewinternet.org/2012/11/01/howteens-do-research-in-the-digital-world/

Pew Internet Project. 2013. Teens, Social Media, and Privacy, Washington, D.C.: Pew Internet \& American Life Project.

Schaefer, D., Simpkins, S., Vest, A., \& Price, C. (2011). The contribution of extracurricular activities to adolescent friendships: New insights through social network analysis. Developmental Psychology, 47, 1141-1152.

Servon, Lisa. 2002. Bridging the Digital Divide: Community, Technology and Policy (Blackwell).

Schmitt, J. \& Wadsworth, J. (2006). Is There an Impact of Household Computer Ownership on Children's Educational Attainment in Britain? Economics of Education Review, 25, 659673.

Subrahmanyam, K., Greenfield, P., Kraut, R., \& Gross, E. (2001). The impact of computer use on children's and adolescents' development. Applied Developmental Psychology, 22, 730 .

U.S. Department of Education (2012). Digest of Education Statistics 2012. National Center for Education Statistics, Institute of Education Sciences, U.S. Department of Education. Washington, DC.

Vigdor, Jacob L., Helen F. Ladd, and Erika Martinez. 2014. "Scaling the Digital Divide: Home Computer Technology and Student Achievement,” Economic Inquiry. 52(3): 1103-1119.

Zavodny, M. (2006). Does Watching Television Rot Your Mind? Estimates of the Effect on Test Scores. Economics of Education Review 25, 565-573. 
Appendix Table 1: Follow-Up Survey Questions for Measures of Social Development

A. Social development related to computer use

A1. Do you ever show your parents how to do something on the computer?

A2. Do you have a social networking page (MySpace, Facebook or Hi5 page)?

A3. Over the past school year have you ever been bullied, teased, or threatened online or by email?

A4. Over the past school year have you ever received help on school assignments from other students, friends, or teachers by email, instant messaging or networking?

$\underline{\text { B. Social development related to interaction with friends }}$

B1. In a normal week, about how many friends do you communicate with (phone, email, instant messaging, etc...) after school, at night, or on the weekends?

B2. In a normal week, about how many friends do you hang out with after school, at night, or on the weekends?

B3. In a normal week (7 days), how many nights do you hang out with friends outside of your home or someone else's home?

B4. How many hours do you spend per week in the following activities? hanging out with friends (at malls, movies, houses, etc.)

$\underline{\text { C. Social development related to sports, clubs and other after-school activities }}$

C1. Do you participate on a sports team?

C2. How many hours do you spend per week in the following activities? playing sports or exercising

C3. Do you participate in school clubs or any other after-school activities?

C4. How many hours do you spend per week in the following activities? In other after-school activities (clubs, Boy/Girl Scouts, etc.) 
Appendix Table 2

Z-Scores for Summary Measures of Social Participation

\begin{tabular}{lcccc}
\hline & $\begin{array}{c}\text { Hanging out with } \\
\text { friends summary }\end{array}$ & $\begin{array}{c}\text { Sports, clubs and } \\
\text { other activities } \\
\text { summary }\end{array}$ & $\begin{array}{c}\text { School } \\
\text { participation } \\
\text { summary }\end{array}$ & $\begin{array}{c}\text { All three } \\
\text { categories } \\
\text { summary }\end{array}$ \\
\hline Treatment effect & 0.10 & 0.01 & -0.03 & 0.01 \\
Observations & $(0.05)^{*}$ & $(0.05)$ & $(0.03)$ & $(0.03)$ \\
Control mean & 636 & 826 & 1044 & 586 \\
Control std. dev. & -0.05 & 0.00 & 0.01 & -0.04 \\
\hline
\end{tabular}

Notes. OLS regressions are estimated for each specification. Heteroscedasticity-consistent standard errors are reported in parentheses. To create the indices we first calculate z-scores for each of the underlying dependent variables by subtracting the control group mean and dividing by the control group standard deviation. The index is then calculated from an equally-weighted average of the z-scores for the underlying dependent variables.

***, **, * indicates significance at 1,5 and $10 \%$. 


\begin{tabular}{|c|c|c|c|c|c|c|c|}
\hline \multicolumn{8}{|c|}{$\begin{array}{l}\text { Appendix Table } 3 \\
\text { Heterogeneity by Baseline Demographic Characteristics }\end{array}$} \\
\hline & (1) & (2) & (3) & $(4)$ & (5) & (6) & (7) \\
\hline & $\begin{array}{l}\text { Hours of } \\
\text { computer use }\end{array}$ & $\begin{array}{l}\text { Bullied online } \\
\text { or via email }\end{array}$ & $\begin{array}{c}\text { Friends } \\
\text { communicate } \\
\text { with per week }\end{array}$ & $\begin{array}{l}\text { Hours hanging } \\
\text { out with } \\
\text { friends per } \\
\text { week }\end{array}$ & $\begin{array}{l}\text { Friends } \\
\text { summary z- } \\
\text { score }\end{array}$ & $\begin{array}{c}\text { Sports, clubs } \\
\text { and activities } \\
\text { z-score }\end{array}$ & $\begin{array}{c}\text { School } \\
\text { participation z } \\
\text { score }\end{array}$ \\
\hline \multicolumn{8}{|l|}{ Panel A. Female Interaction } \\
\hline Treatment & $\begin{array}{c}2.01 \\
(0.68)^{* * *}\end{array}$ & $\begin{array}{c}0.03 \\
(0.03)\end{array}$ & $\begin{array}{c}2.25 \\
(0.89)^{* *}\end{array}$ & $\begin{array}{c}0.92 \\
(0.57)\end{array}$ & $\begin{array}{c}0.10 \\
(0.08)\end{array}$ & $\begin{array}{l}-0.02 \\
(0.07)\end{array}$ & $\begin{array}{l}-0.01 \\
(0.05)\end{array}$ \\
\hline Female student & $\begin{array}{l}-0.69 \\
(0.58)\end{array}$ & $\begin{array}{l}-0.01 \\
(0.03)\end{array}$ & $\begin{array}{c}0.33 \\
(0.82)\end{array}$ & $\begin{array}{l}-0.49 \\
(0.50)\end{array}$ & $\begin{array}{c}-0.16 \\
(0.07)^{* *}\end{array}$ & $\begin{array}{c}-0.33 \\
(0.06)^{* * *}\end{array}$ & $\begin{array}{c}-0.10 \\
(0.05)^{* *}\end{array}$ \\
\hline Female student $*$ treatment & $\begin{array}{c}1.04 \\
(0.99)\end{array}$ & $\begin{array}{c}0.00 \\
(0.04)\end{array}$ & $\begin{array}{l}-1.74 \\
(1.17)\end{array}$ & $\begin{array}{l}-0.53 \\
(0.73)\end{array}$ & $\begin{array}{l}-0.01 \\
(0.11)\end{array}$ & $\begin{array}{c}0.07 \\
(0.10)\end{array}$ & $\begin{array}{l}-0.04 \\
(0.06)\end{array}$ \\
\hline Observations & 755 & 852 & 820 & 847 & 636 & 826 & 1044 \\
\hline \multicolumn{8}{|l|}{ Panel B. Latino Interaction } \\
\hline Treatment & $\begin{array}{c}2.41 \\
(0.67)^{* * *}\end{array}$ & $\begin{array}{c}0.02 \\
(0.03)\end{array}$ & $\begin{array}{c}1.10 \\
(0.97)\end{array}$ & $\begin{array}{c}1.15 \\
(0.73)\end{array}$ & $\begin{array}{c}0.12 \\
(0.10)\end{array}$ & $\begin{array}{c}0.08 \\
(0.07)\end{array}$ & $\begin{array}{l}-0.05 \\
(0.05)\end{array}$ \\
\hline Latino & $\begin{array}{c}0.03 \\
(1.04)\end{array}$ & $\begin{array}{l}-0.17 \\
(0.12)\end{array}$ & $\begin{array}{c}2.25 \\
(1.61)\end{array}$ & $\begin{array}{l}-0.68 \\
(1.96)\end{array}$ & $\begin{array}{l}-0.05 \\
(0.22)\end{array}$ & $\begin{array}{l}-0.04 \\
(0.17)\end{array}$ & $\begin{array}{c}0.11 \\
(0.09)\end{array}$ \\
\hline Latino $*$ treatment & $\begin{array}{c}0.20 \\
(0.91)\end{array}$ & $\begin{array}{c}0.03 \\
(0.04)\end{array}$ & $\begin{array}{c}0.50 \\
(1.20)\end{array}$ & $\begin{array}{l}-0.91 \\
(0.84)\end{array}$ & $\begin{array}{l}-0.04 \\
(0.12)\end{array}$ & $\begin{array}{l}-0.11 \\
(0.10)\end{array}$ & $\begin{array}{c}0.04 \\
(0.07)\end{array}$ \\
\hline Observations & 755 & 852 & 820 & 847 & 636 & 826 & 1044 \\
\hline \multicolumn{8}{|l|}{ Panel C. Grade Interactions } \\
\hline Treatment & $\begin{array}{c}2.44 \\
(0.64)^{* * *}\end{array}$ & $\begin{array}{c}0.01 \\
(0.03)\end{array}$ & $\begin{array}{c}1.20 \\
(0.89)\end{array}$ & $\begin{array}{c}1.27 \\
(0.58)^{* *}\end{array}$ & $\begin{array}{c}0.10 \\
(0.07)\end{array}$ & $\begin{array}{c}0.06 \\
(0.06)\end{array}$ & $\begin{array}{l}-0.05 \\
(0.04)\end{array}$ \\
\hline Grade $6 *$ treatment & $\begin{array}{c}0.39 \\
(1.80)\end{array}$ & $\begin{array}{c}0.07 \\
(0.07)\end{array}$ & $\begin{array}{c}0.11 \\
(1.84)\end{array}$ & $\begin{array}{c}-1.88 \\
(1.12)^{*}\end{array}$ & $\begin{array}{l}-0.07 \\
(0.18)\end{array}$ & $\begin{array}{l}-0.09 \\
(0.16)\end{array}$ & $\begin{array}{l}-0.13 \\
(0.13)\end{array}$ \\
\hline Grade $8+*$ treatment & $\begin{array}{c}0.11 \\
(1.02)\end{array}$ & $\begin{array}{c}0.03 \\
(0.04)\end{array}$ & $\begin{array}{c}0.37 \\
(1.27)\end{array}$ & $\begin{array}{l}-1.05 \\
(0.78)\end{array}$ & $\begin{array}{c}0.01 \\
(0.11)\end{array}$ & $\begin{array}{l}-0.08 \\
(0.10)\end{array}$ & $\begin{array}{c}0.06 \\
(0.07)\end{array}$ \\
\hline Observations & 755 & 852 & 820 & 847 & 636 & 826 & 1044 \\
\hline
\end{tabular}


Table 1

Individual Level Summary Statistics and Balance Check

\begin{tabular}{|c|c|c|c|}
\hline & Control & Treatment & $\begin{array}{c}\text { Equality of } \\
\text { means } p \text { - } \\
\text { value }\end{array}$ \\
\hline \multicolumn{4}{|l|}{ Student and family characteristics } \\
\hline Age & 12.91 & 12.90 & 0.91 \\
\hline Female & 0.51 & 0.50 & 0.66 \\
\hline Ethnicity = African American & 0.13 & 0.14 & 0.86 \\
\hline Ethnicity = Latino & 0.56 & 0.55 & 0.76 \\
\hline Ethnicity = Asian & 0.12 & 0.14 & 0.42 \\
\hline Ethnicity = White & 0.16 & 0.14 & 0.56 \\
\hline Immigrant & 0.21 & 0.18 & 0.15 \\
\hline Primary language is English & 0.43 & 0.43 & 0.97 \\
\hline Parent's education & 12.81 & 12.76 & 0.64 \\
\hline Number of people living in household & 4.98 & 5.02 & 0.79 \\
\hline Lives with mother & 0.92 & 0.89 & 0.12 \\
\hline Lives with father & 0.58 & 0.58 & 0.90 \\
\hline Does your mother have job? & 0.47 & 0.46 & 0.68 \\
\hline Does your father have a job? & 0.73 & 0.70 & 0.36 \\
\hline
\end{tabular}

Notes. $N=1,123$. Columns 1 and 2 report means. Column 3 reports the $p$-value for the t-test for the equality of means.

$* * *, * *, *$ indicates significance at 1,5 and $10 \%$. 
Table 2

Effect of Program on Computer Ownership and Usage

\begin{tabular}{|c|c|c|c|c|}
\hline \multirow[b]{2}{*}{$\begin{array}{l}\text { Owns a } \\
\text { Computer }\end{array}$} & \multirow[b]{2}{*}{$\begin{array}{l}\text { Has Internet } \\
\text { Connection }\end{array}$} & \multicolumn{3}{|c|}{ Hours of Computer Use Per Week } \\
\hline & & At Home & At School & $\begin{array}{l}\text { At Other } \\
\text { Location }\end{array}$ \\
\hline
\end{tabular}

Panel A. Computer Ownership and

Usage

$\begin{array}{lcccccc}\text { Treatment } & 0.55 & 0.24 & 2.52 & 2.59 & -0.02 & -0.05 \\ & (0.03)^{* * *} & (0.03)^{* * *} & (0.48)^{* * *} & (0.31)^{* * *} & (0.17) & (0.30) \\ \text { Observations } & 852 & 831 & 755 & 755 & 755 & 755 \\ \text { Control mean } & 0.26 & 0.17 & 4.23 & 0.76 & 1.59 & 1.89 \\ \text { Control std. dev. } & 0.44 & 0.38 & 5.22 & 2.31 & 2.32 & 3.98\end{array}$

Hours of Computer Use Per Week

\begin{tabular}{|c|c|c|c|c|}
\hline Schoolwork & Email & Games & $\begin{array}{c}\text { Net- } \\
\text { working }\end{array}$ & Other \\
\hline
\end{tabular}

Panel B. Activities on Computer

$\begin{array}{lccccc}\text { Treatment } & 0.77 & 0.42 & 0.83 & 0.59 & 0.18 \\ & (0.25)^{* * *} & (0.12)^{* * *} & (0.24)^{* * *} & (0.18)^{* * *} & (0.11) \\ \text { Observations } & 671 & 671 & 671 & 671 & 671 \\ \text { Control mean } & 1.89 & 0.25 & 0.84 & 0.57 & 0.62 \\ \text { Control std. dev. } & 2.57 & 0.72 & 1.81 & 1.79 & 1.39\end{array}$

Notes: OLS or LPM regressions are estimated for each specification. Heteroscedasticity-consistent standard errors are reported in parentheses. Dependent variables are from a follow-up survey completed by students. Regressions control for the sampling strata (school*year) and baseline characteristics (age, gender, ethnicity, grade, parental education, whether the student's primary language is English, whether the student is an immigrant, number of people living in household, whether the mother/father lives with the student, and whether the mother/father has a job). To avoid dropping observations, for each variable, we create a dummy equal to 1 if the variable is missing for a student and code the original variable as a 0 (so that the coefficients are identified from those with non-missing values).

***, **, * indicates significance at 1, 5 and $10 \%$. 
Table 3

Social Development Related to Computer Use

\begin{tabular}{lcccc}
\hline & $\begin{array}{c}\text { Show parents } \\
\text { how to do } \\
\text { something on } \\
\text { computer }\end{array}$ & $\begin{array}{c}\text { Do you have a } \\
\text { social } \\
\text { networking } \\
\text { page? }\end{array}$ & $\begin{array}{c}\text { Bullied online or } \\
\text { via email }\end{array}$ & $\begin{array}{c}\text { Received help } \\
\text { from teacher or } \\
\text { classmate via } \\
\text { Internet / email }\end{array}$ \\
\hline Treatment effect & 0.43 & 0.09 & 0.03 & 0.02 \\
Observations & $(0.03)^{* * *}$ & $(0.04)^{* *}$ & $(0.02)$ & $(0.03)$ \\
Control mean & 700 & 692 & 852 & 851 \\
Control std. dev. & 0.12 & 0.53 & 0.08 & 0.37 \\
\hline
\end{tabular}

Notes. LPM regressions are estimated for each specification. Heteroscedasticity-consistent standard errors are reported in parentheses. Dependent variables are from a follow-up survey completed by students. Regressions control for the sampling strata (school*year) and baseline characteristics (age, gender, ethnicity, grade, parental education, whether the student's primary language is English, whether the student is an immigrant, number of people living in household, whether the mother/father lives with the student, and whether the mother/father has a job). To avoid dropping observations, for each variable, we create a dummy equal to 1 if the variable is missing for a student and code the original variable as a 0 (so that the coefficients are identified from those with non-missing values).

***, **, * indicates significance at 1, 5 and $10 \%$. 
Table 4

Social Development Related to Interactions with Friends

\begin{tabular}{|c|c|c|c|c|c|}
\hline & $\begin{array}{c}\text { Friends } \\
\text { communicate } \\
\text { with per week }\end{array}$ & $\begin{array}{l}\text { Friends hang out } \\
\text { with outside }\end{array}$ & $\begin{array}{l}\text { Nights hang out } \\
\text { outside }\end{array}$ & $\begin{array}{l}\text { Hours per week } \\
\text { hanging out with } \\
\text { friends }\end{array}$ & $\begin{array}{l}\text { Hours per week } \\
\text { phone and } \\
\text { texting with } \\
\text { friends }\end{array}$ \\
\hline Treatment effect & $\begin{array}{c}1.57 \\
(0.59)^{* * *}\end{array}$ & $\begin{array}{c}0.31 \\
(0.45)\end{array}$ & $\begin{array}{c}0.22 \\
(0.16)\end{array}$ & $\begin{array}{c}0.72 \\
(0.39)^{*}\end{array}$ & $\begin{array}{c}0.03 \\
(0.49)\end{array}$ \\
\hline Observations & 820 & 837 & 679 & 847 & 846 \\
\hline Control mean & 6.71 & 5.62 & 1.72 & 3.16 & 3.38 \\
\hline Control std. dev. & 8.19 & 6.52 & 1.89 & 5.16 & 7.19 \\
\hline \multicolumn{6}{|c|}{$\begin{array}{l}\text { Notes. OLS regressions are estimated for each specification. Heteroscedasticity-consistent standard errors are reported } \\
\text { in parentheses. Dependent variables are from a follow-up survey completed by students. Regressions control for the } \\
\text { sampling strata (school*year) and baseline characteristics (age, gender, ethnicity, grade, parental education, whether } \\
\text { the student's primary language is English, whether the student is an immigrant, number of people living in household, } \\
\text { whether the mother/father lives with the student, and whether the mother/father has a job). To avoid dropping } \\
\text { observations, for each variable, we create a dummy equal to } 1 \text { if the variable is missing for a student and code the } \\
\text { original variable as a } 0 \text { (so that the coefficients are identified from those with non-missing values). } \\
\text { ***,**, * indicates significance at } 1,5 \text { and } 10 \% \text {. }\end{array}$} \\
\hline
\end{tabular}


Table 5

Social Development Related to Sports, Clubs and Other After-School Activities

\begin{tabular}{|c|c|c|c|c|}
\hline & $\begin{array}{c}\text { Sports team } \\
\text { participation }\end{array}$ & $\begin{array}{l}\text { Hours per week } \\
\text { playing sports }\end{array}$ & $\begin{array}{c}\text { School } \\
\text { club/after- } \\
\text { school activity } \\
\text { participation }\end{array}$ & $\begin{array}{l}\text { Hours per week } \\
\text { in after-school } \\
\text { activities }\end{array}$ \\
\hline Treatment effect & $\begin{array}{l}-0.01 \\
(0.03)\end{array}$ & $\begin{array}{c}0.42 \\
(0.28)\end{array}$ & $\begin{array}{l}-0.03 \\
(0.03)\end{array}$ & $\begin{array}{c}0.02 \\
(0.16)\end{array}$ \\
\hline Observations & 850 & 849 & 846 & 844 \\
\hline Control mean & 0.36 & 2.59 & 0.38 & 0.92 \\
\hline Control std. dev. & 0.48 & 3.28 & 0.49 & 2.22 \\
\hline \multicolumn{5}{|c|}{$\begin{array}{l}\text { Notes. OLS or LPM regressions are estimated for each specification. Heteroscedasticity-consistent standara } \\
\text { errors are reported in parentheses. Dependent variables are from a follow-up survey completed by } \\
\text { students. Regressions control for the sampling strata (school*year) and baseline characteristics (age, } \\
\text { gender, ethnicity, grade, parental education, whether the student's primary language is English, whether } \\
\text { the student is an immigrant, number of people living in household, whether the mother/father lives with } \\
\text { the student, and whether the mother/father has a job). To avoid dropping observations, for each variable, } \\
\text { we create a dummy equal to } 1 \text { if the variable is missing for a student and code the original variable as a } 0 \\
\text { (so that the coefficients are identified from those with non-missing values). } \\
* * *, * * * \text { indicates significance at } 1,5 \text { and } 10 \% \text {. }\end{array}$} \\
\hline
\end{tabular}


Table 6

Social Development Related to School Participation and Engagement

\begin{tabular}{|c|c|c|c|c|c|}
\hline & Total Absences & $\begin{array}{l}\text { Unexcused } \\
\text { Absences }\end{array}$ & $\begin{array}{l}\text { Number of } \\
\text { Tardies }\end{array}$ & $\begin{array}{c}\text { Days } \\
\text { Suspended }\end{array}$ & $\begin{array}{l}\text { Still enrolled at } \\
\text { End of Year }\end{array}$ \\
\hline \multicolumn{6}{|c|}{ Panel A. Number of Times } \\
\hline Treatment effect & $\begin{array}{c}-0.63 \\
(0.61)\end{array}$ & $\begin{array}{l}-0.33 \\
(0.39)\end{array}$ & $\begin{array}{l}-0.26 \\
(0.93)\end{array}$ & $\begin{array}{l}-0.30 \\
(0.29)\end{array}$ & \\
\hline Observations & 1044 & 1104 & 1104 & 1106 & \\
\hline Control mean & 10.81 & 4.94 & 11.53 & 1.41 & \\
\hline Control std. dev. & 11.87 & 7.84 & 17.00 & 6.50 & \\
\hline \multicolumn{6}{|c|}{ Panel B. Percentage with at Least One Occurrence } \\
\hline Treatment effect & $\begin{array}{c}0.00 \\
(0.02)\end{array}$ & $\begin{array}{c}0.01 \\
(0.02)\end{array}$ & $\begin{array}{l}-0.03 \\
(0.02)\end{array}$ & $\begin{array}{c}0.00 \\
(0.02)\end{array}$ & $\begin{array}{c}0.01 \\
(0.02)\end{array}$ \\
\hline Observations & 1044 & 1104 & 1104 & 1106 & 1123 \\
\hline Control mean & 0.86 & 0.65 & 0.87 & 0.17 & 0.88 \\
\hline Control std. dev. & 0.35 & 0.48 & 0.34 & 0.37 & 0.33 \\
\hline
\end{tabular}

Notes. OLS or LPM regressions are estimated for each specification. Heteroscedasticity-consistent standard errors are reported in parentheses. Dependent variables are from school-provided administrative data. Regressions control for the sampling strata (school*year) and baseline characteristics (age, gender, ethnicity, grade, parental education, whether the student's primary language is English, whether the student is an immigrant, number of people living in household, whether the mother/father lives with the student, and whether the mother/father has a job). To avoid dropping observations, for each variable, we create a dummy equal to 1 if the variable is missing for a student and code the original variable as a 0 (so that the coefficients are identified from those with non-missing values).

$* * *, * *, *$ indicates significance at 1,5 and $10 \%$. 


\begin{tabular}{|c|c|c|c|c|c|c|c|}
\hline \multicolumn{8}{|c|}{\begin{tabular}{|l} 
Table 7 \\
Heterogeneity by Baseline Social Participation and Parental Control \\
\end{tabular}} \\
\hline 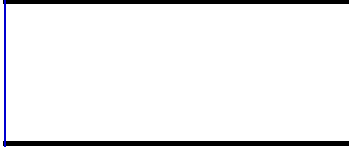 & $\begin{array}{c}\text { Hours of } \\
\text { computer use }\end{array}$ & $\begin{array}{l}\text { Bullied online } \\
\text { or via email }\end{array}$ & $\begin{array}{c}\text { Friends } \\
\text { communicate } \\
\text { with per week }\end{array}$ & $\begin{array}{c}\text { Hours } \\
\text { hanging out } \\
\text { with friends } \\
\text { per week }\end{array}$ & $\begin{array}{l}\text { Friends } \\
\text { summary z- } \\
\text { score }\end{array}$ & $\begin{array}{c}\text { Sports, clubs } \\
\text { and activities } \\
\text { z-score }\end{array}$ & $\begin{array}{c}\text { School } \\
\text { participation } \\
\text { z-score }\end{array}$ \\
\hline \multicolumn{8}{|c|}{ Panel A. Hang out with Many Friends at Baseline } \\
\hline Treatment effect & $\begin{array}{c}2.13 \\
(0.64)^{* * *}\end{array}$ & $\begin{array}{c}0.04 \\
(0.03)\end{array}$ & $\begin{array}{c}1.15 \\
(0.75)\end{array}$ & $\begin{array}{c}0.24 \\
(0.53)\end{array}$ & $\begin{array}{c}0.12 \\
(0.07)^{*}\end{array}$ & $\begin{array}{c}0.01 \\
(0.06)\end{array}$ & $\begin{array}{l}-0.03 \\
(0.04)\end{array}$ \\
\hline $\begin{array}{l}\text { Hang out with many friends } \\
\text { at baseline }\end{array}$ & $\begin{array}{c}0.38 \\
(0.55)\end{array}$ & $\begin{array}{c}0.01 \\
(0.03)\end{array}$ & $\begin{array}{c}3.12 \\
(0.83)^{* * *}\end{array}$ & $\begin{array}{c}0.70 \\
(0.54)\end{array}$ & $\begin{array}{c}0.34 \\
(0.07)^{* * *}\end{array}$ & $\begin{array}{c}0.15 \\
(0.06)^{* *}\end{array}$ & $\begin{array}{c}0.11 \\
(0.05)^{* *}\end{array}$ \\
\hline Many friends * treatment & $\begin{array}{c}0.82 \\
(1.00)\end{array}$ & $\begin{array}{c}0.00 \\
(0.04)\end{array}$ & $\begin{array}{c}0.48 \\
(1.18)\end{array}$ & $\begin{array}{c}0.93 \\
(0.81)\end{array}$ & $\begin{array}{c}-0.02 \\
(0.11)\end{array}$ & $\begin{array}{c}0.01 \\
(0.09)\end{array}$ & $\begin{array}{c}0.00 \\
(0.06)\end{array}$ \\
\hline Observations & 720 & 815 & 787 & 811 & 621 & 794 & 1003 \\
\hline \multicolumn{8}{|c|}{ Panel B. Parents have Curfew at Baseline } \\
\hline Treatment effect & $\begin{array}{c}4.07 \\
(1.32)^{* * *}\end{array}$ & $\begin{array}{c}0.05 \\
(0.05)\end{array}$ & $\begin{array}{c}0.64 \\
(1.39)\end{array}$ & $\begin{array}{l}-0.84 \\
(0.69)\end{array}$ & $\begin{array}{c}0.02 \\
(0.11)\end{array}$ & $\begin{array}{c}0.09 \\
(0.11)\end{array}$ & $\begin{array}{l}-0.09 \\
(0.07)\end{array}$ \\
\hline Have curfew at baseline & $\begin{array}{c}0.01 \\
(0.81)\end{array}$ & $\begin{array}{l}-0.01 \\
(0.04)\end{array}$ & $\begin{array}{l}-1.31 \\
(1.19)\end{array}$ & $\begin{array}{c}-1.54 \\
(0.54)^{* * *}\end{array}$ & $\begin{array}{l}-0.10 \\
(0.10)\end{array}$ & $\begin{array}{c}0.06 \\
(0.08)\end{array}$ & $\begin{array}{l}-0.03 \\
(0.06)\end{array}$ \\
\hline Curfew $*$ treatment & $\begin{array}{l}-1.63 \\
(1.40)\end{array}$ & $\begin{array}{l}-0.01 \\
(0.05)\end{array}$ & $\begin{array}{c}1.09 \\
(1.52)\end{array}$ & $\begin{array}{c}1.84 \\
(0.81)^{* *}\end{array}$ & $\begin{array}{c}0.09 \\
(0.13)\end{array}$ & $\begin{array}{l}-0.07 \\
(0.12)\end{array}$ & $\begin{array}{c}0.09 \\
(0.08)\end{array}$ \\
\hline Observations & 723 & 813 & 784 & 808 & 606 & 788 & 998 \\
\hline
\end{tabular}




\begin{tabular}{|c|c|c|c|c|c|c|c|}
\hline \multicolumn{8}{|c|}{$\begin{array}{l}\text { Table } 8 \\
\text { Heterogeneity by Baseline Social Communication } \\
\end{array}$} \\
\hline & $\begin{array}{l}\text { Hours of } \\
\text { computer use }\end{array}$ & $\begin{array}{l}\text { Bullied online } \\
\text { or via email }\end{array}$ & $\begin{array}{c}\text { Friends } \\
\text { communicate } \\
\text { with per week }\end{array}$ & $\begin{array}{c}\text { Hours } \\
\text { hanging out } \\
\text { with friends } \\
\text { per week }\end{array}$ & $\begin{array}{c}\text { Friends } \\
\text { summary z- } \\
\text { score }\end{array}$ & $\begin{array}{l}\text { Sports, clubs } \\
\text { and activities } \\
\text { z-score }\end{array}$ & $\begin{array}{c}\text { School } \\
\text { participation } \\
\text { z-score }\end{array}$ \\
\hline \multicolumn{8}{|c|}{ Panel A. No Social Networking Page at Baseline } \\
\hline Treatment effect & $\begin{array}{c}3.40 \\
(0.71)^{* * *}\end{array}$ & $\begin{array}{l}-0.01 \\
(0.04)\end{array}$ & $\begin{array}{l}-0.68 \\
(1.05)\end{array}$ & $\begin{array}{l}-0.50 \\
(0.61)\end{array}$ & $\begin{array}{l}-0.09 \\
(0.09)\end{array}$ & $\begin{array}{l}-0.10 \\
(0.07)\end{array}$ & $\begin{array}{l}-0.04 \\
(0.06)\end{array}$ \\
\hline $\begin{array}{l}\text { No social networking } \\
\text { page at baseline }\end{array}$ & $\begin{array}{c}0.53 \\
(0.50)\end{array}$ & $\begin{array}{c}-0.07 \\
(0.03)^{* *}\end{array}$ & $\begin{array}{c}-4.44 \\
(0.94)^{* * *}\end{array}$ & $\begin{array}{c}-1.51 \\
(0.58)^{* * *}\end{array}$ & $\begin{array}{c}-0.31 \\
(0.08)^{* * *}\end{array}$ & $\begin{array}{l}-0.06 \\
(0.07)\end{array}$ & $\begin{array}{c}-0.11 \\
(0.05)^{* *}\end{array}$ \\
\hline No social networking & -1.20 & 0.06 & 3.02 & 1.84 & 0.28 & 0.18 & 0.01 \\
\hline * treatment & $(0.95)$ & $(0.04)$ & $(1.25)^{* *}$ & $(0.78)^{* *}$ & $(0.11)^{* *}$ & $(0.10)^{*}$ & $(0.07)$ \\
\hline Observations & 743 & 840 & 811 & 835 & 627 & 814 & 1032 \\
\hline \multicolumn{8}{|c|}{ Panel B. No Text Messages at Baseline } \\
\hline Treatment effect & $\begin{array}{l}2.87 \\
(0.87)^{* * *}\end{array}$ & $\begin{array}{c}0.01 \\
(0.04)\end{array}$ & $\begin{array}{c}1.07 \\
(1.12)\end{array}$ & $\begin{array}{l}-0.21 \\
(0.79)\end{array}$ & $\begin{array}{c}0.03 \\
(0.09)\end{array}$ & $\begin{array}{l}-0.13 \\
(0.08)\end{array}$ & $\begin{array}{l}-0.03 \\
(0.06)\end{array}$ \\
\hline $\begin{array}{l}\text { No text messages at } \\
\text { baseline }\end{array}$ & $\begin{array}{c}0.32 \\
(0.54)\end{array}$ & $\begin{array}{l}-0.04 \\
(0.03)\end{array}$ & $\begin{array}{c}-3.94 \\
(0.96)^{* * *}\end{array}$ & $\begin{array}{c}-1.58 \\
(0.60)^{* * *}\end{array}$ & $\begin{array}{c}-0.27 \\
(0.08)^{* * *}\end{array}$ & $\begin{array}{c}-0.15 \\
(0.07)^{* *}\end{array}$ & $\begin{array}{l}-0.07 \\
(0.05)\end{array}$ \\
\hline No text messages * & -0.54 & 0.05 & 0.62 & 1.37 & 0.11 & 0.18 & -0.03 \\
\hline treatment & $(1.06)$ & $(0.05)$ & $(1.32)$ & $(0.91)$ & $(0.11)$ & $(0.10)^{*}$ & $(0.07)$ \\
\hline Observations & 717 & 806 & 783 & 802 & 605 & 783 & 988 \\
\hline
\end{tabular}

